\title{
Climate-influenced migration in Bangladesh: the need for a policy realignment
}

Maxmillan Martin ${ }^{1}$, Yi hyun Kang ${ }^{2}$, Motasim Billah ${ }^{3}$, Tasneem Siddiqui ${ }^{4}$, Richard Black ${ }^{5}$ and Dominic

Kniveton ${ }^{6}$

Abstract

Recent research into migration in Bangladesh has highlighted that people migrate for better livelihoods, not necessarily in response to climatic stresses and shocks. If facilitated appropriately, internal and international migration can help build adaptive capacity to future environmental and climatic hazards. In this framing, migration happens in the context of a growing city-centred economy that promotes remittances to villages. However, a textual analysis of current and recent policies concerning climate change, development and poverty alleviation, and disaster management shows that the economic and adaptive roles of internal migration are often not included in policy framing. We argue that if migration works as a positive step towards adaptation, then the key challenge is to align the policies with this new understanding.

\section{Introduction}

Exposed to frequent and extreme climatic events (Findlay and Geddes 2011, Black et al 2013, Penning-

Rowsell 2013), and being one of the most vulnerable countries in the context of climate change (Huq 2001), Bangladesh requires effective climate adaption measures (Planning Commission 2012). Adaptation involves adjustments to natural or human systems in response to actual or expected climatic stimuli in order to moderate harm or make use of beneficial opportunities (McCarthy et al 2001; IPCC 2012). It could include a set of activities, decisions and attitudes in different aspects of life in line with existing social norms and processes (Adger et al 2005). Migration is one such activity: indeed, a number of qualitative, quantitative and synthesis studies suggest that migration can be an effective form of adaptation to climate change (Barnett and Webber 2010, Foresight 2011, Hunter et al 2015, Koubi et al 2016, McLeman and Smit 2006, Tacoli 2009). Bangladesh is a country with high levels of internal and external migration (Afsar 2003, Gardner

\footnotetext{
${ }^{1}$ Department of Anthropology, University College London, and Department of Geography, University of Sussex. Corresponding author: max.martin@sussex.ac.uk

${ }^{2}$ Environmental Policy Research Centre, Freie Universität Berlin

${ }^{3}$ Refugee and Migratory Movements Research Unit, University of Dhaka

${ }^{4}$ Refugee and Migratory Movements Research Unit, and Department of Politics, University of Dhaka

${ }^{5}$ Centre for Migration and Diaspora Studies, SOAS, University of London

${ }^{6}$ Department of Geography, University of Sussex

This article has been accepted for publication and undergone full peer review but has not been through the copyediting, typesetting, pagination and proofreading process, which may lead to differences between this version and the Version of Record. Please cite this article as doi:
}

10.1111/dpr. 12260

This article is protected by copyright. All rights reserved. 
2009); yet the major policy concern to date is not how to mobilise migration as a form of adaptation, but whether climate change will increase climatic variability and/ or the frequency of extreme events, thus adding to migration flows (Black et al. 2011). We argue in this paper that if migration is seen as a positive step towards adaptation, a range of policies could encourage and facilitate it, rather than ignoring or inhibiting it.

Climate stresses and sudden shocks in Bangladesh, including water shortage, cyclone, floods and coastal/ delta erosion (EM-DAT, 2011) are expected to affect livelihoods and habitat safety in the coming decades (Adams et al. 2011). As elsewhere, such stresses and shocks are likely to influence migrations, largely within the country or to nearby countries (Foresight, 2011). The potential benefits of migration described and debated in the development literature are potentially applicable in a climate change scenario as well. In this debate, optimists see remittances from internal and external migrants as precursors to resource availability and improved income distribution in origin areas (Spaan et al 2005). Pessimists see out-migration as a mark of economic dependency, and undermining prospects for local development (Heremele 1997). Alternative readings, especially the 'time perspective' (Rahman 2009), suggest that though the negative costs might dominate in the short term, migration ultimately stimulates development. Further, it has been argued that it is the structural context in a country that determines whether the benefits of migration aids or blocks development goals (de Haas 2012). Such a perspective suggests that for migration to promote development, what is needed are 'attractive investment environments and trust in political and legal institutions in the origin countries [and regions]', and especially conditions in which relatively poor and lower skilled people have access to residency rights, education and employment (de Haas 2012: 21).

However, despite these varied perspectives on migration in general, literature and policies tend to be more universally pessimistic about migration influenced by climate change (Barnet and Webber, 2009). For instance, in most countries, National Adaptation Programmes of Action (NAPAs), the basic plans for adaptation in Least Developed Countries (LDCS), frame migration as a problem, or a failure of adaptation (Sward and Codjoe 2012). Such negative attitudes could limit policy options and benefits of migration (Laczko and Aghazarm 2009) or even confine people to vulnerable places (Foresight 2011). Such restrictive policies also rarely succeed (de Haas 2006; World Bank 2010).

This article is protected by copyright. All rights reserved. 
After the following section on the conceptual framework and methods, this paper briefly examines the patterns and drivers of migration in Bangladesh from the perspective of climate change adaptation. It then considers in detail to what extent different government policies in Bangladesh - concerning climate change, development, and disaster risk reduction - try to mainstream migration into development planning and explore its potential as a climate change adaptation measure. Based on this examination, the paper suggests there is considerable scope for policy reorientation, to acknowledge and promote the adaptive capacity of migration rather than inhibiting it.

\section{Concepts, approaches, method}

\subsection{Policy analysis framework and method}

The study of public policy transcends disciplinary boundaries, as 'what governments do' covers economic, social and political spheres (Minogue 1983: 63). Policies concerning climate-related migration require a particularly broad look across these fields, since the drivers of such migration are themselves spread across social, political, environmental, economic and demographic spheres (Foresight 2011, Black et al 2011). Inter-relationships among these factors as well as action and inaction of stakeholders could influence the policy-making process (Keeley and Scoones, 1999). This paper looks at the policy scenario in Bangladesh in the context of changing migration patterns within the country in the context of climate change and variability and largely urban-based economic growth.

To analyse policies, Patton and Sawicki (1993) have proposed a six-step approach, comprising problem definition, determination of evaluation criteria, identification of alternatives, comparison of alternatives, and assessment of outcomes. Drawing on this approach, we define the problem here as whether or not policies acknowledge migration as a climate change adaptation strategy in Bangladesh. To address this problem, we evaluated key policy documents in the fields of migration, climate change, development and disaster management. Out of various methods of policy analysis (Gorden et al. 1993), we analysed policy content to examine the extent to which specific policies mention migration, and where they do, the extent to which it is framed as an adaptation strategy in the face of climate change.

This article is protected by copyright. All rights reserved. 
We took a textual analysis route as the policy language illuminates what 'ideas, values and interests' are given preference in governance (lannantuono and Eyles 1997: 1611). As Bourdieu (1991) argues, language works as a means to promote ideologies and words become a medium of power. We tried to probe how specific policies view and describe migration in the context of climate change and associated events and processes such as increased exposure to extreme weather events and livelihood losses (IPCC 2014). We evaluated whether these policies encourage, discourage, or keep quiet about such migration. What is not said, or 'silences in discourse' could be interesting, since silence could be a way of accommodating two or more irreconcilable values (Yanow 1992: 399). Instead of identifying and comparing alternative policies, we compared policies that complement one another, as climate-related migration is a phenomenon that is relevant to overlapping policy spheres. Due to the number of policy documents analysed, we have not attempted an in-depth understanding of the textual nuances and symbolic values, but the enquiry is limited to probing the government's stated view on climate-related migration and its potential contribution to climate change adaptation.

\subsection{The concept of adaptive migration}

The concept of adaptation has gained international attention within the discourse on climate change, notably in follow ups to the Copenhagen Accord that made an urgent call for 'enhanced action and international cooperation on adaptation' (UNFCCC, 2011: 2). The Intergovernmental Panel on Climate Change (IPCC) defines adaptation as an adjustment in natural or human systems in response to actual or expected climatic stimuli or their effects to moderate harm or exploit beneficial opportunities (McCarthy et al 2001, IPCC 2012). It includes activities, decisions and attitudes in tune with social norms and processes (Adger et al, 2005). Adaptive capacity is defined as 'the ability of a system to adjust to climate change (including climate variability and extremes) to moderate potential damages, to take advantage of opportunities, or to cope with the consequences' (IPCC, 2007, p.869). Physical components such as infrastructure, food and nutritional insecurity, employment and accessibility of public service are critical determinants of adaptive capacity (Saroar and Routray, 2012 p.186). As the causes and consequences of migration often overlap with the concerns outlined above, migration can work as an adaptation strategy in more ways than one.

A growing body of scientific evidence posits migration as an effective adaptation strategy that offsets the impacts of environmental shocks and stresses (McLeman and Smit 2006, Barnett and Webber 2009, Tacoli

This article is protected by copyright. All rights reserved. 
2009, Foresight 2011, ADB 2012). The argument is that migration can offset the vulnerability of households to the impact of climate change. For example, migration can enhance households' adaptive capacity by improving access to resources, livelihood strategies, social networks, and accessibility to markets (Gerlitz et al.2014). Migration as an adaptation method covers a spectrum of motives and outcomes - from moving out of an area of risk exposure (Adger et al. 2005, IPCC 2012, Penning-Rowsell 2013), surviving extreme events, aiding disaster recovery (Findlay and Geddes 2011, Black et al 2013) and improving and diversifying livelihoods when faced with soil degradation and erratic rainfall (Tacoli 2011). Remittances from migrants may also boost adaptive capacity (Guzman et al. 2009, Warner et al. 2009) as research in Burkina Faso, India and Mexico suggest (Foresight 2011). To put it succinctly, migration works as a reasoned response embedded in existing livelihood patterns (Gardner 2009).

However, though migration has been used as an adaptation to climate-related vulnerability (Banerjee et al, 2012), it is also influenced by socio-economic and other factors. According to the New Economics of Labour Migration (NELM) theory, migration can be seen as a strategy to minimise risk, reduce consumption and diversify income (Stark and Bloom 1985). Such a strategy becomes even more important in the face of climate- and environment-related stresses and shocks that undermine livelihoods and habitat safety. Migration has long been considered and practiced as a form of environmental adaptation, though it is only one among many ways to adapt (Hunter et al 2015) in a wide spectrum of livelihood choices that complement one another (Kniveton et al. 2008). Meanwhile it is important to understand that climatic and environmental changes influence drivers of migration across a range of overlapping social, political, economic, environmental and demographic spheres (Foresight 2011, Black et al. 2011). Different factors in these five spheres, including disasters, development projects, environmental degradation, shortages, poverty and market changes, can often act together to amplify vulnerabilities (Stal and Warner 2009). The question here is how people offset these vulnerabilities by migrating for short or long durations to nearby villages or faraway cities or even overseas.

In this context, this paper draws on a comprehensive research project in Bangladesh that extended from quantitative and qualitative analysis of migration itself, to an analysis of policy documents designed to examine the extent to which government policies acknowledge, support and facilitate migration as an adaptive measure. The qualitative component of this research examined the behavioural aspects of migration

This article is protected by copyright. All rights reserved. 
decision-making in the context of changes in economy, and environment (Martin et al. 2014). In turn, a quantitative study was undertaken comprising the 30-year life histories of 1380 respondents in three districts exposed to different climate-related hazards - Nawabganj, Satkhira and Munshiganj - based on a retrospective longitudinal questionnaire. The questions covered details of family, housing, livelihood, assets, migration patterns and social networks. The study also included weather data and testing of the sensitivity of migratory movements to climatic stresses and shocks. The methods included event history analysis and logistic regression. The results are currently under review for publication.

This paper focuses on an analysis of climate and development policies in Bangladesh, and the extent to which they reflect an 'adaptive' approach to migration. We focus on a range of policies, including documents that deal specifically with climate change (such the country's NAPA, and subsequent Bangladesh Climate Change Strategy and Action Plan (BCCSAP). The analysis also covers policies that deal with development, notably the country's Sixth Five Year Plan (2011-15) and Outline Perspective Plan (to 2021), as well as its Poverty Reduction Strategy Papers (PRSP) and the Millennium Development Goals (MDG) progress report; and policies that deal with disasters, notably the National Plan for Disaster Management (2010-15). Beyond seeing policy-making as a linear process, we looked at the interlinkages between various policies that frame government action on climate change, development, disaster risk reduction and migration. However, before moving to this analysis, the following section describes how migration patterns in Bangladesh are influenced by climatic stresses and shocks.

\section{Patterns and drivers of migration in Bangladesh}

\subsection{Current trends}

Significant flows of migration have occurred in Bangladesh in recent decades in the context of changing opportunities for employment and income generation. The share of agriculture in GDP fell from $32 \%$ to $19 \%$ during 1980 to 2010 and industry grew from 21\% to 28\% (Muzzini and Aparicio 2013). That has meant rapid urbanization, with one of the world's highest average annual rate of change (from rural to urban) at $2.4 \%$, compared with an Asian average of 1.5 during 2010 - 2015 (UN 2014). In the past two decades, overall

This article is protected by copyright. All rights reserved. 
population growth in the country was $29 \%$, showing a $24 \%$ increase in rural and $49 \%$ increase in urban areas (Marshall and Rahman 2013). The proportion of people living in cities has reached $23.43 \%$ in 2011. It was a mere $2.43 \%$ in 1901 . The urban population growth rate has shown a dramatic increase during 19611974 (137.6\%), 1974-1981 (115.8\%) and 1981-1991 (65.9\%). However, Bangladesh still remains a predominantly rural country with about $76.57 \%$ of its people living in villages (BBS 2014).

One of the key drivers of this migration is economic opportunity. By working in different locations for short or long periods before returning, migrants try to earn more and save enough to help themselves and their families back home. Yet at the same time, short-term and circular internal migration can be seen as an adaptation strategy for households in districts such as Nawabganj, Satkhira and Munshiganj, as climatic stresses and shocks undermine livelihoods.

A proportion of migrants move short distances to nearby towns. Others migrate to major metropolitan cities of Dhaka and Chittagong. The 2011 census (BBS 2012) notes that Bangladesh has an internal migration rate - defined as lifetime migration outside each district per thousand people - of 9.7, with rural-to-urban movements comprising 4.3 per thousand, rural-to-rural 4.2 per thousand, urban-to-urban 0.86 per thousand and urban-to-rural 0.36 per thousand. In contrast, the international migration rate is 3.46 (ibid).

\subsection{Drivers of migration}

Economic push and pull factors - such as slow-placed rural development amidst poverty and urban growth - drive migration. Migration - of all of these types - can form an important source of income. In northwestern Bangladesh, a 1,600-household survey carried out as part of the Livelihood Monitoring Project found $19 \%$ of households migrate in the lean farming season to supplement their income (Care Bangladesh and DFID 2002). Major rural-to-rural migration takes place during sowing and harvest seasons for the same reason. Bangladeshis villages provide the necessary labour force for the country's growing manufacturing sector, including the garment industry, and the large informal sector that has developed around these industry hubs. Still the economic development is still city-based with Dhaka and Chittagong taking major share of it till recently (Marshall and Rahman 2013).

This article is protected by copyright. All rights reserved. 
Urban growth has been uneven, led by the Dhaka metropolitan area with an estimated population of 15 million, followed by Chittagong with around 5 million people. These two big cities along with Khulna, Rajshahi, Barisal, Sylhet, Comilla and Rangpur account for about 36 million out of Bangladesh's 160 million population, largely on account of a rising share of industrial production in Bangladesh's GDP (Muzzini and Aparicio 2013). During 2001-2011, the peri-urban hinterlands of Dhaka and Chittagong have shown major growth. On the contrary, coastal areas have shown slow growth, with the districts of Khulna and Barisal recording much lower rates of growth compared with the national average (Marshall and Rahman 2013).

In the cities, many migrants find jobs as rickshaw pullers and in informal sectors such as brick kilns and construction or are self-employed in urban and peri-urban areas. In Dhaka, rickshaw-pullers alone numbered about 500,000 in 2005 , constituting a total of two million people including their dependents and others closely associated with them (Kreibich 2012). However, it is not economic opportunities alone that drive migration. For example, the social networks of migrants, comprising kinship ties and neighbourhood friendships, are critical in supporting new migration. As discussed above, climate- and environment-related events and changes influence migration patterns in many ways.

International migration is another facet of the picture. The top destinations include India, Saudi Arabia, the UK, Kuwait, Oman, the US and Malaysia (UN 2013a, Bangladesh Bank 2015). International remittances have been growing even during the global slowdown after 2008 (Siddiqui 2009) rising to 15316.9 million US dollars by $2014-15$ - that is about $8.86 \%$ of the country's GDP of 172.9 billion dollars - as table 1 shows (Bangladesh Bank 2015, World Bank 2016):

Table 1 Remittances to Bangladesh:

\begin{tabular}{|l|c|c|c|c|c|c|}
\hline Financial year & $\begin{array}{c}2009- \\
2010\end{array}$ & $\begin{array}{c}2010- \\
2011\end{array}$ & $\begin{array}{c}2011- \\
2012\end{array}$ & $\begin{array}{c}2012- \\
2013\end{array}$ & $\begin{array}{c}\text { 2013- } \\
\mathbf{2 0 1 4}\end{array}$ & $\begin{array}{c}\text { 2014- } \\
\mathbf{2 0 1 5}\end{array}$ \\
\hline Remittances in million USD & 10987.40 & 11650.33 & 12843.44 & 14461.13 & 14228.32 & 15316.90 \\
\hline
\end{tabular}

(Bangladesh Bank 2015)

International remittances have been growing even during the global slowdown after 2008

This article is protected by copyright. All rights reserved. 
Remittances have helped reduced poverty and there is an argument that more emigration could improve the country's economy (Moses 2009). International movement also includes crossing the border to India. Historically there have been migratory and refugee movement between eastern and western parts of Bengal. The 2001 Indian national census counted 3 million Bangladeshi migrants, though some estimates suggest higher figures. There has been continued migration to India from the Khulna region, partly due to the effects of the Farakka Barrage on the Indian side that diverts part of the Ganges flow (Swain 1996).

Whether it is long or short distance, migration decisions often involve a comparative assessment of the benefits and costs of different livelihood choices; an individual's own perceived ability to change their lives; and the extent to which individuals trust and are influenced by family, friends, peers and those in authority. Changes in livelihood patterns are also influenced by work opportunities as well as vulnerabilities (Entwisle et al. 2005) and migration is a reasoned response embedded in social lives and livelihoods of people (Gardner 2009).

Sometimes people move out of their villages due to environmental drivers, after droughts, floods or storm surges that destroy their fields or leave them salinised. Our qualitative study shows that people across all the three study areas perceive that their climate is changing and livelihoods are becoming increasingly difficult (Martin et al. 2014). Migration decisions may be based in part on the likelihood and severity of environmental threats and a set of behavioural factors that influence whether such external stimuli are taken into account.

Climate-influenced migration could range from displacement after climatic shocks such as cyclones or livelihood difficulties as a result of a drought. Frequent cyclones are one of the main environmental drivers of migration. After Cyclone Aila in 2009, many people moved to other towns due to lack of working opportunities in the affected areas. Failures in cropping and shrimp farming due to salinisation could also alter migration patterns (WARPO 2006). After hazards, people move to safety and the landless among them move for income recovery (Penning-Rowsell et al. 2013). However, families prefer to stay put and migration appears to be the last resort.

This article is protected by copyright. All rights reserved. 
More gradually developing stresses on livelihood could lead to the establishment of forms of circular migration. During times of monga or seasonal food scarcity and lack of employment during September to November, people migrate, especially from northern parts of Bangladesh. Landless people often end up in poverty and hunger and every year boys and men from monga-affected areas migrate to cities and betteroff villages (Siddiqui 2009). Large-scale, but often unplanned, shrimp farming in the southern coastal belt has led to salinisation of the soil, and lower yields from rice fields (Rahman et al 2013). Growing water stress and climate variability reduce agricultural productivity, helping to drive rural-urban migration. Besides, riverbank erosion displaces 50,000 to 200,000 people in Bangladesh every year (Mehedi 2010). As it destroys farms and homes (Zaman 1989), sometimes communities get displaced several times (Hutton and Haque 2003). For example, a study by Abrar and Azad (2004) in northwest Bangladesh found that on an average, households have been displaced 4.6 times by riverbank erosion. In a projected scenario of climate change, there is a likelihood of low-lying parts of delta islands and coasts getting inundated and pushing the salinity line further north, causing further water stress and crop losses (Adams et al, 2011).

In scenarios that involve clear risks from climate- and environment-related hazards, often the government and international organisations have attempted planned relocation of people in Bangladesh. Sometimes environmental protection measures required relocation of people. For instance, the Coastal Embankment Rehabilitation Project (CERP) of 1995 - 2003 comprised building and strengthening of embankments and drainage structures, and reforestation as a protection against cyclone impacts. The project affected 4,866 landowners, requiring resettlement of 543, and relocation of 1156 squatters (World Bank 2005). The Guchhogram Climate Victims Rehabilitation Project provides another example of a resettlement. Launched in 2009 , it is a three-year project 'to settle the climate victims, landless, homeless, address-less and river eroded people on khas land or donated land with living accommodation and to make all such rehabilitated families owner of a piece of homestead land' (MoL 2009). It involved rehabilitation of 10,650 landless families by establishing 207 villages. By 2012-13, as the government data suggests, 8,958 families have been rehabilitated in 198 villages spread across all the seven divisions of Bangladesh (Guchhogram [CVRP] Project 2013a).

This article is protected by copyright. All rights reserved. 
Conceptually, Guchhogram is a follow up of the Poragacha Cluster Village initiative that Sheikh Mujibur Rahman (the first president of Bangladesh) started in 1972, a year after his nationalist party led the liberation of the country. One of the triggers for the liberation war, along with political discontent, was the ineffective response of the erstwhile government of the undivided Pakistan to a cyclone in 1970 that killed an estimated 250,000 people (Heitzman and Worden 1989). On Rahman's advice, the Ministry of Land Administration and Land Reforms rehabilitated 1,470 landless families affected by cyclone and riverbank erosion in the char (riverine island) areas of the Greater Noakhali district in four cluster villages. Later the government rehabilitated 45,647 families in 1080 adarsha grams (ideal villages) in Adarsha Gram Project-I, and 25,385 families in 427 villages in the second phase of the project (Guchhogram [CVRP] Project 2013b).

Though the Guchhogram project has been criticised for being too small considering the scale of the problem of displacement (YPSA 2013), it could be seen as an example of responding to forced migration on account of climatic and environmental reasons. In a context that sees people migrating out of hazard-prone and underdeveloped coastal villages for better livelihoods elsewhere (Marshall and Rahman 2013) and the general scenario of migrants ending up in unplanned urban slums (MOEF 2008, Kreibich 2012, Muzzini and Aparicio 2013), such initiatives possibly offer a model for future. The prospect of planned resettlement of people affected by climate change is a matter of emerging international research attention (de Sherbinin et al 2011, Ferris 2012, for instance).

Demographic pressures make up another driver for migration. At 1,087 people per square kilometre, Bangladesh has one of the highest population densities in the world (UN 2013b). Research in Bangladesh suggests that the impacts of cyclones and storm surges on infrastructure and habitats depend not only on the hazard exposure and intensity, but also demographic factors, along with socio-economic and cultural factors (Paul and Rautray 2011). For instance, while very intense tropical cyclones cause heavy damage in lowlying coastal areas in general, irrespective of socio-economic levels, at lower intensities the poorest still suffer heavy losses (Peduzzi et al. 2012). Moreover, though the frequency of tropical cyclones may be reducing, projected increases in their intensity combined with demographic pressures could increase the number of people exposed to risk and contribute to more migration (Peduzzi et al. 2012, Adams et al.2011). At the

This article is protected by copyright. All rights reserved. 
same time, climatic stresses could affect demographics not only in terms of temporary and short-term displacement or migration, but also on a longer term. An analysis of the latest census figures (BBS 2012, Marshall and Rahman 2013) suggests that the population growth rate in the coastal region - including urban areas - is lower than that in the more developed central areas of Bangladesh. While the explanation for this differential rate of growth is migration on account of the lower economic growth of the region, there are indications that hazards such as cyclones and floods also play a role (Marshall and Rahman 2013). In this framing, migration is not necessarily a step to regain lost livelihood or to get a better one, but also an effective adaptation or risk aversion strategy in response to a changing environment.

Local politics and social dynamics could also trigger migration. Many communities in Bangladesh are under the power of local mafias (Raillon 2010) that gain control over accretion lands by using violence. They often use violence and making resettlement a socio-political issue (Zaman 1989). Although the Government promotes rehabilitation by moving the landless and the displaced to char areas formed of riverine silt, the new settlers are often intimidated by the local powers and many have to go back to their original regions. Vested interest groups in rural and urban areas occupy those lands by using unjust power (Planning Commission 2011). Public opposition against land grabbing is growing, forcing the Government to take steps to correct unjust actions (Feldman and Geisler 2011). Unequal and unjust land distribution patterns further add to the vulnerability of people. In the char areas where land tenure is temporary and ad hoc, poor people try to settle in newly formed land masses. However, powerful talukdars and jotedars (chieftains) often gain control over such land by force. The government is trying to secure better land tenure rights for the migrants.

In short, movements vary greatly in terms of their drivers as well as time and space dimensions. Among such movements, seasonal and circular migration is often an important livelihood strategy for people living in hazard-prone places. Such short-term migration is often hard to measure with multiple trips of various time spans and distances. Bell (2004) has identified nine discrete dimensions of temporary population movements: [i] movement intensity (the population who engage in temporary moves) [ii] duration of stay [iii] frequency of movement [iv] periodicity [v] seasonality [vi] movement distance [vii] spatial circuits (outwards and return journeys) [viii] spatial connectivity and [ix] spatial impact (net economic gain or loss, for instance). However, accurate recall could be difficult in a retrospective survey (as we used in our research).

This article is protected by copyright. All rights reserved. 
Though there are toolkits that capture everyday mobility at discrete points in time as suggested by Bell (2004) among others, such an approach was beyond the scope of our study.

Our analysis shows that economically driven migration could have environmental influences. Internal, cross-border and international migration patterns are to some extent sensitive to climate change as the impacts of increased flooding and storm surges sharply enhance the income differentials between rural and urban/ international livelihoods. However, the loss of assets from climate change also reduces the ability of households to engage in the costlier types of migration.

\subsection{Migration policies}

Reflecting the varied drivers of migration in Bangladesh, government policy on migration has been similarly ambiguous, starting from a position of seeking to monitor and regulate it, building on the 1982 Emigration Ordinance which was devised at a time of significant labour demand in the Gulf states. As labour dynamics changed, there have been periods of restrictions on migration, notably in response to the exploitation of migrant workers, and especially migrant women. However, over recent years, policy towards migration in Bangladesh has become much more open and facilitative, in part through the demands of migrant workers and their families, and in part through recognition of the positive role that migration has played in a number of communities.

One example of this more open approach to migration policy is the Overseas Employment Policy, 2006, which sets out the right of male and female workers from Bangladesh to choose overseas employment. It is aimed at regularising migration movements from all parts of the country. It protects the rights, dignity, and security of the migrant workers within and outside of the country. It also seeks to ensure social protection of their families that stay back, and commits to strengthen the policy implementation mechanism (Siddiqui and Farah, 2011). A follow-up legislation titled the Overseas Employment and Migration Act 2013 upholds and protects migrants' rights based on the principle of non-discrimination. It allows supported emergency return of migrants if their host country is in any kind of crisis. It tries to prevent fraudulent practices and enforces accountability of recruiting agencies and their sub-agents. It also has a provision for functioning sub-agents. In the past, migrants could not go directly to court against the misconduct of a recruiting agency. The new law also allows a migrant to move court if the concerned government official fails to take

This article is protected by copyright. All rights reserved. 
legal action in time in such cases. Before its enactment, the draft law has gone through civil society consultation, and was presented to the Ministry of Law, Justice and Parliamentary Affairs (Siddiqui and Farah 2011, Siddiqui 2011). Apart from the above provisions, this law enhances the safety of women's migration, and makes recruiting agencies more accountable (MOF 2014).

Such reforms are necessary in the context of urbanization and industrialization, which it is argued inevitably leads to migration as part of a 'single symbiotic process' (Marshall and Rahman 2013: 5). If that is the case, internal migration - along with international migration - is necessary for economic growth and poverty alleviation in the country. The Government of Bangladesh has taken this approach in its recent policy documents. The MDG Progress Report 2011 (Planning Commission 2012), for instance, places migration in the context of economic development, as well as environmental concerns. Meanwhile, the Sixth Five Year Plan (Planning Commission 2011), Ten Year Perspective Plan (Planning Commission 2010) and the National Strategy for Accelerated Poverty Reduction (Planning Commission 2009) all acknowledge the importance of short-term international labour migration in the economic development of the country. However, rural to urban flows, especially to the metropolitan core, are not generally talked about so much in government documents. However, it may be noted that the government recently has initiated a set of studies and learning measures to address this lacuna.

The following section addresses the extent and manner in which they are addressed in policies on climate change, poverty reduction, and disaster management in particular.

4. The framing of migration within wider public policies in Bangladesh

As the above section shows, people's migration on different scales of distance and time is often - but not necessarily - influenced by climatic factors. Long-term and short-term international migration is weakly sensitive to climate change. Though cross-border movement to India often has a climate 'nexus' (in terms of water stress, crop loss and disasters), tighter border control over the past decade has reduced the scope of such movement to a great extent (Martin et al 2014). That leaves disaster-related displacement and short-term internal migration in Bangladesh as the movements most sensitive to climate change and variability. Amid changes in extreme event and disaster trends (IPCC 2012, Adams et al. 2011) and migration

This article is protected by copyright. All rights reserved. 
patterns in areas of high exposure to hazard such as the coastal belt (BBS 2012, Marshall and Rahman 2013), it is likely that more people will migrate in a changing climate (Adams et al. 2011). Given the record of migration in Bangladesh as mentioned above, we argue that such migration could contribute to better standards of living and resilience at their home and destination, effectively becoming an effective adaptation strategy. This section examines whether the existing policy environment acknowledges this adaptive role of climate-related migration.

\subsection{Policies and documents dealing with climate change}

Bangladesh has drawn up a national framework as mandated by the UN Framework Convention on Climate Change for the least developed countries (LDCs) and submitted its National Adaption Programme of Action (NAPA) in 2005. Subsequently, the Climate Change Unit of the Ministry of Environment and Forests (MoEF) brought out the Bangladesh Climate Change Strategy and Action Plan (BCCSAP) in 2008, which was revised in 2009. The NAPA was also updated in 2009. For follow-up activities, the government set up a Climate Change Trust Fund (CCTF) in 2009, which has approved 43 government projects with a US $\$ 70$ million allocation, besides 32 NGO projects with US $\$ 3.5$ million in allocations. In addition, the Bangladesh Climate Change Resilience Fund (BCCRF) - based on public finance - has been put in place with development partners pledging of US $\$ 113.5$ million. The resilience fund is being managed and implemented by the Government with the World Bank's technical assistance. There are also plans to set up a multi-donor Trust Fund (MDTF) for receiving and disbursing adaptation funds (UNFCCC 2014). During 2009-12, the government allocated US\$350 million from its non-development budget and approved 107 projects worth an estimated 1,272 million Bangladeshi Taka (US \$ 16.4 million) in climate-vulnerable areas (Pervin 2013). The government also draws from multilateral development banks and agencies for low-carbon resilient development (LCRD) investments. These donors include the World Bank, ADB and International Finance Corporation. Other major intermediaries include the Global Environment Facility (GEF) and national banks including the Central Bank (Pervin and Moin 2014).

Starting off its planned response to climate change, the Government of Bangladesh submitted its NAPA to the UNFCCC in 2005, recognising that climate change will amplify the impacts of natural hazards, and made

This article is protected by copyright. All rights reserved. 
an urgent call to integrate adaptive measures (MOEF, 2005). It projected the following problems: fresh water scarcity, drainage congestion, river bank erosion, frequent floods, prolonged drought and salinity in the coastal zone. It acknowledged the enhanced vulnerability of coastal areas, farm yield reduction and the risk of future food-grain insufficiency (MOEF 2005).

Overall, the 2005 NAPA treated migration as an undesirable outcome of climate change. For example, a diagram in the document mentions migration along with crime as an outcome of livelihood impacts of climate change through employment, income and consumption ( $p$ 17). The argument illustrated by the diagram is that climate change has an impact on farming, health, infrastructure, industry and disaster patterns and, in turn, food security. As employment, income, and consumption patterns are affected, people might resort to 'adjustment mechanisms' that include migration and crime.

Project no 11 promotes adaptation to coastal crop agriculture to combat salinisation. Its long-term outcomes include community adaptation to flood/ tidal surge and sea level rise. And it adds: 'Affected community would not migrate to cities for job and livelihood' ( $p 35$ ); and 'Social consequences of mass scale migration to cities would to some extent be halted' ( $p$ 36). Project no 12 is concerned with adaptation by farms in the flood-prone North East and Central regions. Its outcome is envisaged as a reduction in migration: 'In the long-term people might get a means to continue with farming, instead of migrating to cities after the flood. This would to some extend reduce social problems of migration of the distressed community to cities' ( $p$ 37).

In contrast, the updated NAPA of 2009 moved from dealing with immediate and urgent needs to cover wider adaptation needs. It focused on four security issues, namely, food, energy, water and livelihood (including right to health), and respect for local community on resource management and extraction (MOEF, 2009). The project list was expanded further. Importantly, most of the negative references to migration in the original NAPA were deleted, with the exception of the diagram on $\mathrm{p} 17$. Our interviews suggest that the Awami League government that came to power in 2008 broadly supported the NAPA and BCCSAP prepared by their preceding government, but favoured something distinct in their newer version. They selected migration as an issue that shows this distinctiveness. However, although NAPA and BCCSAP were updated, still the revised documents do not envisage migration as an explicit adaptation strategy.

This article is protected by copyright. All rights reserved. 
While the NAPA mainly listed immediate priorities, BCCSAP focused on medium and long-term goals. It focused on six key areas - food security, social protection and health, comprehensive disaster management, infrastructure research and knowledge management, mitigation low carbon development and capacity building and institutional strengthening. The original 2008 version projected a worst case climate scenario: '...unless existing coastal polders are strengthened and new ones built, sea level rise could result in the displacement of millions of people' (MOEF, 2008: 1). The document predicted that hundreds of thousands of people would be forced to migrate, especially from coastal zones, because of decreasing livelihood opportunities and lowering agricultural productivity. It estimated that 6-8 million people could be displaced by 2050 (MOEF 2008). In addition, slums in big cities were referred to as a highly likely destination for those who migrate. Considering the fast and unplanned ongoing urbanisation in Bangladesh, this was framed as posing an impending problem (ibid: 16). Despite the acknowledgement of significant migration due to climate change, the BCCSAP did not outline a clear policy response.

The updated 2009 version of the BCCSAP addresses the issue of migration in more detail. On the one hand, it updated the figures of displacement due to sea level change, salinity, cyclones and storm surges to a staggering 20 million and suggests the need for resettlement of these 'environmental refugees', possibly abroad. Yet at the same time, it states that: 'Migration must be considered as a valid option of the country', going on to say: 'Preparations in the meantime will be made to convert this population into trained and useful citizens for any country' (MOEF 2009: 17). In the Research and Knowledge Management section of the BCCSAP, the Government also included a new research agenda: 'Monitoring' of climate change-related internal and external migration and rehabilitation (MOEF 2009: 58).

Taken together, the climate policy documents reviewed here provide evidence that migration is framed fundamentally as a growing problem to be addressed in the context of climate change, where policy interventions need to seek to either reduce the need to migrate, or deal with it as a form of forced displacement when it happens. Nonetheless, between the original and revised versions of both the NAPA and the BCCSAP, there is some softening of this line, and in the latter case an appreciation of alternative approaches to migration, where with appropriate training, migrants could be part of the process of rehabilitation of climate affected areas. The extent to which this shift is based on a reasoned examination of evidence, however, or more on party political factors, is unclear.

This article is protected by copyright. All rights reserved. 
4.2 Development and poverty reduction policies

Turning to development planning in Bangladesh, poverty alleviation and social sector development are two major concerns of the government over the past decade. These concerns are reflected across a number of different documents, including those focused on domestic agendas (such as the Sixth Five Year Plan and Outline Perspectives Plan) and those written in response to international agendas (such as the National Strategy for Accelerated Poverty Reduction - Bangladesh's PRSP - and the country's progress report on the Millennium Development Goals).

The Sixth Plan is perhaps the most important document that charts out the development path for the country from 2011 to 2015, and in contrast to policy documents in the climate field, it talks very positively about migration - albeit with a focus on international migration. It welcomes the continued prospects for international labour migration of 400,000 to 500,000 workers a year and permanent labour absorption of about 100,000 workers (Planning Commission 2011). It also notes in a special focus on underdeveloped regions, especially Khulna, Rajshahi, and Barisal Divisions, that development can be achieved in part by promoting international labour migration. However, although migration appears prominently, and is addressed across 15 pages of the Plan, the dynamics and outcomes of internal migration are barely considered. At the same time, the Plan pays considerable attention to 'climate change', its outcomes and adaptation measures, the term appearing 50 times in a 246 page document, with an entire chapter dedicated to environment, climate change and disaster management for sustainable development ( $188-215)$. Yet in so far as migration is mentioned in relation to climate change, the plan's most significant observation is that 70 million people will be displaced due to 'climate-induced flooding, cyclones and storm surges' (p153). This is seen as potentially leading to tremendous pressure on land and natural resources and threatening the gains made in poverty reduction ( $p$ 188-189). One of the key recommendations is to 'mainstream poverty-environment-climate-disaster nexus in the development project design, budgetary process, project implementation and monitoring process' ( $p$ 196).

Out-migration from areas affected by climate change does find some brief mention in the section of the Sixth Plan on climate change ( $p 188, p$ 202). However, the target action points under the themes of food

This article is protected by copyright. All rights reserved. 
security, social protection, disaster management, infrastructure, research, low-carbon development and capacity building do not include migration or ways to deal with it. In short, displacement is seen as a problem created by climate change, but internal migration is not seen as a potential form of adaptation.

Subsequent to the agreement of the Sixth Five Year Plan, the country's Outline Perspective Plan was launched to achieve 'Vision 2021', the national long-term goal for development. Vision 2021 chalks out a development scenario in which citizens will have a higher standard of living, better education, better social justice and a more equitable socio-economic environment. The sustainability of this development will be ensured through a range of measures, notably through better protection from climate change and natural disasters (Planning Commission 2010).

In contrast to the $6^{\text {th }}$ Plan, the Vision 2021 document deals more substantively with migration, both international and internal. However, whilst on the one hand it welcomes remittances from overseas migrants, it also comments extensively, and broadly negatively, on the sharp rise in rural-urban migration. Noting that slums account for more than $35 \%$ of the population in all major Bangladeshi cities, the document expresses the concern that unplanned urbanisation and migration will restrict sustainable economic growth potential in rural areas and create hazards in urban areas. Reflecting this, it suggests that domestic policy should seek to 'reverse' the trend of migration to cities ( $p 68)$, through more spread-out urban development and better livelihood opportunities in villages, as well as 'migration controls' ( $p$ 69). Thus village development is suggested as a remedy to 'weaken the forces of pull and push and inhibit rural to urban migration.' (p 69).

Whilst the $6^{\text {th }}$ Plan and Vision 2021 documents were prepared internally by the Government of Bangladesh, PRSPs are prepared in consultation with development partners, including the World Bank and the IMF. Updated every three years, they describe the country's macroeconomic, structural, and social policies for growth and poverty reduction as well as major sources of financing - indeed, the Sixth Five Year Plan followed up on these findings. The first document came out in 2005 (IMF 2005). One focus of the report (Planning Commission, 2005) was emerging rural-urban continuum, including the dramatic expansion of allweather rural infrastructure developed in the 1980s. It notes that migration and remittances have emerged as dominant factors. It acknowledges that 'migration of varying duration to a variety of destinations both rural and urban as well as near and far is increasingly a critical part of the picture'. It goes on to state that:

This article is protected by copyright. All rights reserved. 
'Initial fears that migration was fuelling an export of poverty from rural to urban areas has now been dispelled by poverty trend statistics; in general, urbanisation appears to have been a force for poverty reduction with urban poverty declining much faster than rural poverty' ((Planning Commission 2005: p xvi).

Still the new policy strategy paper that came out in 2008 (Planning Commission 2008) and its update prepared 'in the light of Election Manifesto of the Bangladesh Awami League 2008' (Planning Commission 2009) did not take the internal migration agenda forward. This latest version stressed the need to enhance flow of remittances and provide loans to international labour migrants (ibid: 20), bringing transparency in the migration process ( $p 24)$, and better training in labour laws of the employing countries ( $p$ 134). The section on 'Tackling Climate Change for Poverty Reduction' (pp89 - 92) talks about livelihoods, disaster risk reduction, forestry and technology- but not migration. For the urban poor and slum dwellers, cooperatives, micro credit organizations and health facility improvements have been envisaged in the Poverty Reduction Plan (Planning Commission 2009). Besides, the new National Urbanisation Policy is expected to address such concerns even more.

Turning to the country's 2012 progress report on the Millennium Development Goals (MDG), the Government of Bangladesh emphasises mainstreaming migration into development, climate change and environment policy for sustainable development. In doing so, the Government said it expects to set up plans that would offset the impacts of environmental change and human mobility challenges over the coming years (Planning Commission 2012: 81). This plan also promotes international migration as remittances - comprising almost $11 \%$ of GDP - are seen as having major beneficial development impacts. It also emphasises special measures for women international migrants.

The report also acknowledges a trend of steady rural-to-urban migration, but frames this trend as further stretching and expanding basic services in cities. The population density in slums is reported as being 200 times the average population density of Bangladesh, which is already the highest in the world (Planning Commission 2012: 80). As a result, the report states that 'Bangladesh faces a Herculean task in sustainably improving the lives of slum dwellers' ( $p$ 81). One of the targets is to achieve a 'significant improvement' in the lives of at least 100 million slum dwellers ( $p$ 75). One of the key recommendations is to provide support for legal migration, remittances and exploring labour markets in the context of international movement

This article is protected by copyright. All rights reserved. 
(pp. 94-96). Recommendations, however, miss the point of internal migration dynamics, except for the welfare of slum-dwellers. Nonetheless, policy documents (Planning Commission 2011, for instance) do address the prospect of large-scale displacement in a changing climate, and the government has tested some planned resettlement projects in response such as the Guchhogram Project as described above.

In addition to such general policy documents on development prospects, the country's Coastal Zone Policy (MoWR, 2005) details measures aimed at management of natural resources, sustainable livelihoods and promotion of renewable energy. It outlines conditions under which 'the coastal people are able to pursue their life and livelihoods within secure and conducive environment' ( $\mathrm{p} 3$ ). Its main principles include the adoption of an integrated process approach, co-management and participatory decision-making, decentralization and development of the private sector ( $\mathrm{p} 2$ ). The policy is aimed at poverty reduction and the promotion of sustainable livelihoods, including the integration of the coastal zone into national processes ( $p 3$ ). One of the main concerns of this policy is disaster management. A rationale for the policy is 'disasters and gradual deterioration of the environment' ( $p 1)$. The policy acknowledges that 19 districts are affected directly or indirectly by tidal waters, salinity intrusion, cyclones and storm surges ( $\mathrm{p} 2$ ). It notes: 'Reduction to vulnerability to natural disasters would be an integral aspect of the national strategies for poverty reduction' ( $p$ 4). It suggests effective early warning measures, dykes, protection against erosion and rehabilitation of people affected (ibid). However, there is not a single mention of the word migration.

\subsection{Disaster Management Policies}

Turning more explicitly to disaster management policies, these have received considerable attention in Bangladesh for much of the past two decades. Between 1991 and 2007, Bangladesh suffered 95 major disasters that claimed 200,000 lives and caused an estimated US $\$ 5.9$ billion in damages especially in farm and infrastructure sectors (MoFDM, 2008). In 2007 Cyclone Sidr killed 4,234 people, and Cyclone Aila of 2009 killed 190 (Roy, 2011). These casualty figures were arguably significantly less than some earlier cyclones thanks to disaster risk reduction programmes including early warning systems. However, more than 400,000 people were displaced in each of these events that caused prolonged damage to agriculture, fisheries, forestry, health, water supply, forcing people to move out (Roy, 2011; OCHA, 2012).

In 2000, the Government initiated a transition from response and relief to comprehensive risk reduction in collaboration with UNDP. The outcome was the Comprehensive Disaster Management Programme (CDMP)

This article is protected by copyright. All rights reserved. 
that was approved in November 2003. It preceded the Hyogo Framework for Action 2005-2015, which the 2005 World Conference on Disaster Reduction formulated (CDKN, 2011). Its Phase I (2004-2009) was a pilot for long-term disaster risk reduction and climate change adaptation in seven districts. At the national level it created policy and planning mechanisms. Phase II (2010-14) built on these. The achievement of phase II objectives envisaged mapping of hazards, risks and vulnerabilities and setting up an early warning system (ibid).

Some of the key documents that spell out the specifics of the policy are the National Plan for Disaster Management, the Disaster Management Act and the draft National Disaster Management Policy. In particular, the National Plan for Disaster Management 2010-2015 is the blueprint for action in this field. In turn, operational aspects have been codified in the Bangladesh Disaster Management Act that was enacted in September 2012 (ECB, 2012). The policy-making process has been undertaken with NGO and community participation in CDMP II with a focus on risk management and mainstreaming.

The National Plan for Disaster Management 2010-2015 aims to address disaster risks comprehensively and reduce the vulnerability of poor to the effects of natural, environmental and human-induced hazards. It aims at a shift in disaster management from conventional response and relief practice to a more comprehensive risk reduction culture and strengthening the capacity of the Bangladesh disaster management system. The plan document (DMRD, 2010) relates to climate change and development policies of the country discussed above. It also explains how different parts of the country become vulnerable to disasters. It analyses the socio-economic dimensions of disasters, and acknowledges the poverty-disaster interface and the impact of disasters on economic and social activities of the poor. It lists depletion of assets, reduced income due to loss of work, and increased indebtedness as factors that increase the vulnerability of the poor. It also notes how the cost to cope is disproportionately higher for the poor (p 36), and acknowledges that floods and riverbank erosion are rendering people homeless. Yet far from addressing the issue of migration as a strategy for poor people to cope with disasters or adapt, in includes out migration as a factor that increases the vulnerability of the poor. Resettlement does receive a passing mention, one of the plans actions being to: 'Disseminate the information for utilization in development planning and resettlement of vulnerable communities' (p73). Yet resettlement - generally a top-down state-led process - is not the same as migration as an adaptation strategy for poor people.

This article is protected by copyright. All rights reserved. 
Similar to the National Plan, the Disaster Management Act and associated policies also address disaster risk in Bangladesh, and make positive contributions to reducing loss of lives and livelihoods in account of disasters. Still they largely overlook migration and its contribution to coping with disasters events or adapting to environmental change.

5. Conclusion: linking climate change, development and migration

There is widespread awareness and a strong political will in policy circles in Bangladesh to acknowledge the impacts of climate change on development and growth. The Sixth Plan document notes: '... climate change will exacerbate the vulnerability of poor people to environmental shocks, with the predicted increase in extreme climate events' (Planning Commission 2011: 165). This understanding is part of the government's efforts to mainstream climate change into the overall planning process. Climate change is not being treated as merely an environmental issue, but a development issue. In turn, the country has developed a more proactive stance towards migration that sees this also as integral to development, even if the focus to date has been on international rather than internal migration.

Even though many policies in Bangladesh are progressive and people-friendly, there is some concern about a lack of co-ordination among different ministries with policies tending to take a silo approach, not accounting for issues addressed in different, but related policy areas. For example, the Overseas Employment Policy that is pursued by the Expatriates' Welfare and Overseas Employment Ministry does not deal with climate change issues; whilst environmental policies pursued by Ministry of Environment do not look into the broader aspect of labour migration that the government is promoting. There is no monitoring and evaluation process built into the policy (Siddiqui 2010, Siddiqui and Farah 2011). However, the Ministry of Expatriate Welfare and Overseas Employment has formed an Inter-Ministerial Committee to review relevant laws with contribution from the International Organization for Migration (IOM 2011). IOM has also facilitated a policy dialogue on mainstreaming concrete short and long-term migration adaptation strategies in Bangladesh on the basis of emerging evidence.

This article is protected by copyright. All rights reserved. 
In addition, whilst the overall view of migration in Bangladesh policy circles is becoming more positive in terms of its potential to promote development, a glaring omission in most of the policies discussed above is a lack of mention of internal migration or its portrayal in negative or, at best, general terms. This has a significant impact on how migration is seen as relating to climate change, as policymakers are now trying to bundle climate change concerns - from disasters to gradual deterioration of the environment and loss of livelihoods - and address them in comprehensive policies. One issue is an apparent conflict of interests between the poor people who migrate to cities in search of work in large numbers and industry and business. The utilization of urban space is a contentious issue. The Sixth Five Year Plan document, for instance, talks about a tremendous pressure on land and natural resources exerted by the migrants (Planning Commission 2011: 188- 189). The Outline Perspective Plan seeks the 'reverse' the trend of migration ( $p$ 68) and put in place 'migration controls' ( $p$ 69). In this document, there is no mention of the role of migration in delivering workers to the growing industrial sector, never mind its role as an adaptation to climate-related shocks in rural areas.

Indeed, although a city-based development pattern in Bangladesh draws people from villages in large numbers, surprisingly absent from government discourse is a proper acknowledgement of the economic contribution of internal migrants and their role in a growing economy. There is mention about changing farming practices and growth of cities - but this knowledge is not translated into an enabling environment for the migrant workers. There are exceptions such as the Guchhogram Project. However, overall the contribution of migrants to the economy largely goes unnoticed. Research and policy measures in general tend to ignore unorganised temporary migrant workers, their agency and rights (Rogaly 2009).

Another aspect of migration that does not find mention in policies is irregular migration to India. This is a thorny issue in bilateral relations, especially after India resorted to tough border control measures (AP 2012). The issue has cropped up in several bilateral meetings of security agencies, and at the Home Minister level. A Coordinated Border Management Plan between the two countries aims to curb illegal border crossings and incidents (Rajya Sabha 2012), even as international agencies such as the IOM are trying to use provisions for cooperation under the South Asian Association for Regional Cooperation (SAARC) Convention to promote a more flexible approach.

This article is protected by copyright. All rights reserved. 
A close look at the migration patterns in Bangladesh shows that more often than not migratory movements are within the country. People often follow regular patterns of short-term, seasonal migration to neighbouring places, supported by social networks. Village-to-village migration and often urban forays help the migrants supplement their livelihoods and tide over tough phases and lean seasons. Often people move back and forth, following regular patterns (Chowdhury et al. 2009; Siddiqui 2009, Findlay and Geddes 2011, Etzold et al. 2013). A common strand that runs through all these scenarios is mobility. Mobility broadly means the freedom to seek opportunities to improve livelihoods, living standards and services such as health care and education - succinctly put, safer and more productive life in more responsive communities (UNDP 2010). It is a broader concept than migration, a fundamental element of human freedom (UNDP 2009).

Migration experts increasingly suggest that policies that consider human mobility succeed and those that restrict it fail (de Haas, 2009). Yet, despite some recognition of the benefits of migration as a climate change adaption strategy, our analysis of key public policies in Bangladesh suggest that the country remains some way off. Efforts at such a policy realignment could start by acknowledging voluntary labour migration - both internal and inter-national -as a way to improve the resilience of climate vulnerable communities and an effective adaptation strategy. Beyond the strategies and projects proposed in NAPA and BCSAS, the government could also frame a comprehensive climate change policy aimed at climate-resilient development, which appreciates the role of migration as a climate change adaptation strategy and address the hardship of displaced people. To ensure that migrants benefit from such a policy, reforms are also needed across different socio-economic and development policies. There is a need to establish the habitat rights of the displaced people in khas (state-owned) and diluvian (flood-related) land. At the same time, labour policy should be made more comprehensive and inclusive to protect the rights of internal migrants - ensuring living wages, access to health care, social safety net and civic services, and safer working and living conditions. Such protection is especially important in construction, garment, and brick kiln industries, where people from climate-vulnerable areas often find work.

This article is protected by copyright. All rights reserved. 
Meanwhile there is a need to focus on areas affected by climatic hazards. A review of the Overseas Employment Policy 2006 would make it easier for people from such areas to obtain short-term international migration contracts. Vocational training facilities such as technical training centres of the Bureau of Manpower Employment and Training (BMET) and the ministries of youth and education could be extended to these areas. The government-run Prabashi Kallyan Bank (Migrants' Welfare Bank) might also offer better services in such areas to provide loans for prospective migrants and to promote enterprises using remittances, thereby enhancing job opportunities. Such creative use of remittances can contribute to local resilience and rebuilding after disasters (Stern 2007). To streamline such intervention, labour and overseas employment ministries would need to have representation in government committees dealing with climate change, such as the Inter-ministerial Climate Change Steering Committee, the technical committee of the Climate Change Trust Fund (CCTF), National Environment Committee, National Committee on Climate Change and Climate Change Unit.

Policy realignment is a political process that requires procedural and administrative interventions. Given the political will, the commitment of the national government to put in place effective climate change adaptation mechanisms and the administrative facilitation of such measures as described above, a reform process that enhances the adaptation role of migration is certainly possible.

Acknowledgment: This article is an outcome of a CDKN-commissioned study by the Sussex Centre for Migration Research, University of Sussex, UK. In response to the Government of Bangladesh's request, it focused on climate change impacts on human displacement, and a review of relevant policies (CDKN 2013). The project partner, Refugee and Migratory Movements Research Unit (RMMRU) at Dhaka University, was later commissioned by CDMP to prepare the National Strategy on the Management of Disaster and Climate Induced Displacement. The strategy paper became part of Bangladesh's planning process (Siddiqui et al 2015).

\section{References}

Abrar, C. R and Azad, S.N.(2004) Coping with Displacement: Riverbank Erosion inNorthwest Bangladesh, Dhaka: RDRS, NBI and RMMRU

This article is protected by copyright. All rights reserved. 
Adams, N., Dasgupta, S., and Sarraf, M. (2011). The cost of adapting to extreme weather events in a changing climate. Bangladesh development series paper; no. 28. Washington DC: The Worldbank. [online] http://documents.worldbank.org/curated/en/2011/12/16203403/cost-adapting-extreme-weather-eventschanging-climate accessed on July 17, 2015.

ADB (2012) Addressing Climate Change and Migration in Asia and the Pacific. Mandaluyong City, Philippines: Asian Development Bank

Adger W N, Arnell N W, Tompkins E L (2005) 'Successful adaptation to climate change across scales.' Global Environmental Change 15: 77-86.

Afsar, R. (2003) Internal migration and the development nexus: the case of Bangladesh, paper presented at the Regional Conference on Migration, Development and Pro-Poor Policy Choices in Asia organized by the Refugee and Migratory Movements Research Unit and DfID, UK, Dhaka, Bangladesh 22-24 June.

Ajzen, I (1991) The theory of planned behavior, Organizational Behavior and Human 673, Decision Processes $50,179-211$.

Alam, K., Shamsuddoha, M., Tanner, T., Sultana, M., Huq, M.J. and Kabir, S. (2011). The Political Economy of Climate Resilient Development Planning in Bangladesh. IDS Bulletin. 42 (3), p52-61.

AP (2012) India pledges zero casualties on Bangladesh border, Dawn.com, World, Urdu Edition, Associated Press, 29 September, Available at:

http://dawn.com/2012/09/29/india-pledges-zero-casualties-on-bangladesh-border/laccessed on October 27, 2012)

Barnett, J. and Webber, M. (2010) Accommodating Migration to Promote Adaptation to Climate Change. World Bank Policy Research Working Paper: no. WPS 5270, Apr 2010. Washington DC: World Bank

Banerjee, S., Black and R. Kniveton, D. (2012) Migration as an effective mode of adaptation to climate change: Policy paper for the European Commission,Brighton: Sussex Centre for Migration Research, University of Sussex

Bangladesh Bank (2015) Wage Earners Remittance inflows: Country wise (Monthly), https://www.bb.org.bd/econdata/wagermidtl.php accessed on March 31, 2016

Bangladesh Bureau of Statistics (2012) Population \& Housing Census 2011: National Report, Volume - 4, Socio-economic and Demographic Report, December 2012, Statistics and Informatics Division, Ministry of Planning, Dhaka: Government of the People's Republic of Bangladesh

(2014) Population \& housing census 2011: National volume - 3, Urban area report, August 2014, Statistics and Informatics Division, Dhaka: Ministry of Planning, Government of the People's Republic of Bangladesh

Barnett, Jon and Michael Webber (2009) Accommodating Migration to Promote Adaptation to Climate Change, Stockholm: Commission on Climate Change and Development

This article is protected by copyright. All rights reserved. 
Bell, MJ. (2004) Measuring temporary mobility: dimensions and issues, Paper presented at the CAUTHE Conference session on Tourism and Temporary Mobilities, Brisbane, 10-13 February

Black, R., Kniveton, D. and Schmidt-Verkerk, K.. (2011) Migration and climate change: towards an integrated assessment of sensitivity. Environment and Planning A. 43, p.431-450.

Black, R., Arnell,N.W., Adger,N.W, Thomas,D. Geddes, A. (2013) Migration, immobility and displacement outcomes following extreme events, Environmental Science \& Policy 27s: s32-s43

Bourdieu, P. (1991) Language and symbolic power, Cambridge: Harvard University Press

CARE-Bangladesh and DFID (2002) The Findings of the Northwest Ruala Livelihoods Baseline -2002 Livelihood Monitoring Project, Dhaka, Bangladesh quoted in Hossain et al (2003)

CDKN (2011) Bangladesh's Comprehensive Disaster Management Programme, Inside stories on climate compatible development, December, London: Climate and Development Knowledge Network

CDKN (2013) Project: Adaptation policy options and interventions for climate change induced displaced people of Bangladesh [online]

https://cdkn.org/project/adaptation-policy-options-and-interventions-for-climate-change-induced-displaced-people-of-bangladesh/?loclang=en gb accessed on March 23, 2017

Chowdhury, S., Mobarak, A. M., \& Bryan, G. (2009). Migrating away from a seasonal famine: A randomized intervention in Bangladesh, Human Development Research Paper 2009/41. New York: UNDP.

de Haas, H. (2009). Mobility and Human Development. Geneva: UNDP

de Haas (2012) The Migration and Development Pendulum: A Critical View on Research and Policy. International Migration, 50: 8-25

de Sherbinin, A., Castro, M., Gemenne, F., Cernea, M.M., Adamo, ., Fearnside, P. M., Krieger, G., Lahmani, S., Oliver-Smith, A., Pankhurst, A., Scudder, T., Singer, B., Tan, Y., Wannier, G., Boncour, P., Ehrhart, C., Hugo, G., Pandey, B., Shi, G. (2011) Preparing for Resettlement Associated with Climate Change. Science, 28 October 2011, Vol. 334: 456-457

Disaster Management and Relief Division (2010) National Plan for Disaster Management 2010-2015, Dhaka Disaster Management Bureau, Disaster Management \& Relief Division Government of the People's Republic of Bangladesh

Emergency Capacity Building (2012) 'Bangladesh Passes Disaster Management Act As ECB Bangladesh Maintains Government Lobbying', Emergency Capacity Building Project, 27 September

EM-DAT (2011) The OFDA/CRED International Disaster Database, Université Catholique de Louvain, Brussels. Available: www.emdat.be

Entwisle, B., Stephen J. Walsh and Ronald R. Rindfuss (2005) Population and Upland Crop Production in Nang Rong, Thailand, Population and Environment, 26 (6): 449-470.

This article is protected by copyright. All rights reserved. 
Etzold, B. Ahmed, A.U. Hassan S. R, and Neelormi, S. (2014) Clouds gather in the sky, but no rain falls. Vulnerability to rainfall variability and food insecurity in Northern Bangladesh and its effects on migration, Climate and Development 6: $18-27$

Feldman, S. and Geisler, C. (2011). Land Grabbing in Bangladesh: In-Situ Displacement of Peasant Holdings. In: Land Deals Politics Initiative (LDPI), the International Conference on Global Land Grabbing. 6-8 April 2011.

Ferris, E. (2012) Protection and Planned Relocations in the Context of Climate Change, Brookings-LSE Project on Internal Displacement, Legal and Protection Policy Series, Division of International Protection, PPLA/2012/04 Geneva: UNHCR

Findlay, A. and Geddes, A. (2011) Critical view on the relationship between climate change and migration: Some insights from the experience of Bangladesh, in Piguet, E., Pécoud, A. and Guchteneire, P. (eds.) 138159.

Fishbein, M. and Ajzen, I. (2010) Predicting and Changing Behaviour: The Reasoned Action Approach, Hove: Psychology Press.

Foresight (2011) Migration and Global Environmental Change, Final Project Report, London: Government Office for Science.

Gardner, K. (2009) Lives in Motion: The Life-Course, Movement and Migration in Bangladesh, Journal of South Asian Studies 4 (2): 229-251.

Gerlitz, JY; Banerjee, S; Hoermann, B; Hunzai, K; Macchi, M (2014) Assessing Poverty, Vulnerability and Adaptive Capacity: Development of a System to Delineate Poverty, Vulnerability, and Adaptive Capacity in the Hindu Kush-Himalayas. ICIMOD: Kathmandu.

Gorden, I., Lewis, J. and Young, K. (1997). Perspectives on policy analysis. In: Hill, M. the Policy Process, a Reader. Hertfordshire: Prentice Hall/Harvester Wheatsheaf. P5-9.

Gordon, I. and Lewis, J. and Young, K. (1993) Perspectives on Policy Analysis in Hill, M. Ed., the Policy Process: A Reader, London: Prentice Hall

Grothmann, T. and Patt, A. (2005). Adaptive capacity and human cognition: The process of individual adaptation to climate change. Global Environmental Change. 15, p199-213.

Guzman, J.M., Martine, G., McGranahan, G., Schensul, D., Tacoli, C (2009). Population Dynamics and Climate Change. New York and London: UNFPA and IIED.

Guchhogram CVRP Project (2013a) Lits of Guchhogram Established upto 2012-2013, [online] http://www.guchhogram.gov.bd/index.php?option=com content\&task=view\&id=477\&ltemid=501 accessed on January 16, 2014

Guchhogram [CVRP] Project (2013b). About Guchhogram http://www.guchhogram.gov.bd/index.php?option=com content\&task=view\&id=463\&ltemid=482accessed on January 16, 2014

Heitzman, J. and Worden, R. eds (1989) Bangladesh: A Country Study. Washington: GPO for the Library of Congress, 1989. Available at http://countrystudies.us/bangladesh/ accessed on January 27, 2014

This article is protected by copyright. All rights reserved. 
Heremele, K. (1997) The discourage on migration and development in Hammar T, Brochmann G, Tamas K, Faist T (eds). In International Migration, Immobility and Development: Multidisciplinary Perspective, Oxford: Berg; 133-158

Hunter L. M., Luna, J. K., \& Norton, R. M. (2015). Environmental dimensions of migration. Annual Review of Sociology, 41(6), 1-21.

Huq, S. 2001: Climate change and Bangladesh. Science 294, 1617.

Iannantuono, A. and Eyles, J. (1997) Meanings in policy: a textual analysis of Canada's 'Achieving Health For All' document. Social Science \& Medicine 44(11):1611-21.

IMF (2005), IMF Country Report No. 05/410, Washington: International Monetary Fund

IOM (2011) IOM-ADB Policy Dialogues on Climate Induced Migration, Geneva (June 9th 2011) and Bangkok (June 16th-17th 2011)

Intergovernmental Panel on Climate Change (2007). Climate Change 2007: Impacts, Adaptation and Vulnerability. Contribution of Working Group II to the Fourth Assessment Report of the Intergovernmental Panel on Climate Change. Cambridge: Cambridge University Press.

(2012) Managing the Risks of Extreme Events and Disasters to Advance Climate Change Adaptation. A Special Report of Working Groups I and II of the Intergovernmental Panel on Climate Change, Cambridge, UK, and New York: Cambridge University Press

( 2014) Climate Change 2014: Synthesis Report. Contribution of Working Groups I, II and III to the Fifth Assessment Report of the Intergovernmental Panel on Climate Change [Core Writing Team, R.K. Pachauri and L.A. Meyer (eds.)]. Geneva: IPCC

Koubi, V, Spilker, G., Schaffer, L. and Bernauer, T (2016) Environmental Stressors and Migration: Evidence from onVietnam, Development 79: 197-210

Kuruppu, N. (2009) Adapting water resources to climate change in Kiribati: the importance of cultural values and meanings, Environmental Science \& Policy 2: 799-809

Laczko, F. and Aghazarm, C.(2009) Migration, the Environment and Climate Change: Assessing the Evidence, Migration Research Series paper 33, International Organization for Migration, Geneva.

Leiserowitz, A (2006) Climate Change Risk Perception and Policy Preferences: The Role of Affect, Imagery, and Values, Climate Change, 77; $45-72$.

Kang, Y. H. (2012) Internal Migration and Adaptation Policy Options in Coastal Bangladesh, Master's Thesis, School of Global Studies, University of Sussex, Brighton

Kniveton, D., Smith, C. and Wood, S. (2011) Agent based model simulations of future changes in migration flows for Burkina Faso, Global Environmental Change, 21, S34-40

This article is protected by copyright. All rights reserved. 
Marshall,R.and Rahman, S. (2013) Internal Migration in Bangladesh: Character, Drivers and Policy Issues, Dhaka: UNDP

Martin, M., Billah, M., Siddiqui, T., Abrar, C., Black, R. and Kniveton, D., 2014. Climate-related migration in rural Bangladesh: a behavioural model. Population and Environment, 36(1), pp.85-110.

McCarthy, J; Canziani, O; Leary, N; Dokken D; White, K (Eds.) (2001) Climate change 2001: Impacts, adaptation and vulnerability. Contribution of Working Group II to the Third Assessment Report of the Intergovernmental Panel on Climate Change. Cambridge: Cambridge University Press.

McLeman, R and Smit, B (2006) 'Migration as an adaptation to climate change.' Climatic Change 76: 31-53

Mehedi, H., Nag, A. K., and Farhana, S. (2010). Climate Induced Displacement - Case Study of Cyclone Aila in the Southwest Coastal Region of Bangladesh. Khulna: Humanitywatch.

Minogue, M. (1983) Theory and Practice in Public Policy and Administration, Policy \& Politics, 11 (1): 63-85

Ministry of Environment and Forests (2005) National Adaptation Programme of Action,, August, Dhaka: Ministry of Environment and Forests, Government of the People's Republic of Bangladesh

( (2008) Bangladesh Climate Change Strategy and Action Plan 2008. Ministry of Environment and Forests, Government of the People's Republic of Bangladesh

(2009) National Adaptation Programme of Action, Updated Version of 2005, August, Dhaka: Ministry of Environment and Forests, Government of the People's Republic of Bangladesh

Ministry of Finance (2014) Ministry of Expatriates' Welfare \& Overseas part of the Budget 2014-2015 statement [online] http://www.mof.gov.bd/en/budget/14 15/gender budget/en/16 65 Expatriate's\%20Welfare\%20and\%200verseas English.pdf accessed on July 29, 2015.

Ministry of Food and Disasters Management (2011) Draft Disaster Management Act 2008. Dhaka: Ministry of Food and Disaster Management, Government of the People's Republic of Bangladesh

(2008) National Disaster Management Policy, Dhaka: Ministry of Food and Disaster Management, Government of the People's Republic of Bangladesh

Ministry of Labour (2009). Guchhogram Project Status, Dhaka: Ministry of Land, Government of the People's Republic of Bangladesh

Moses, J. (2009) Leaving Poverty Behind: A Radical Proposal for Developing Bangladesh Through Emigration, Development Policy Review, 27 (4) 457-479,

Ministry of Water Resources (2005), Coastal Zone Policy 2005, Dhaka: Ministry of Water Resources Government of the People's Republic of Bangladesh

OCHA. (2012). Internal Displacement - Overview. Office for the Coordination of Humanitarian Affairs [online]

This article is protected by copyright. All rights reserved. 
http://www.unocha.org/what-we-do/advocacy/thematic-campaigns/internal-displacement/overview. oline accessed on March 23, 2017.

Patton, V. and Sawicki, D.S. (1993) Basic methods of policy analysis and planning, Englewood Cliffs: Prentice Hall

Paul, S. and Routray, J. (2011). Household response to cyclone and induced surge in coastal Bangladesh: coping strategies and explanatory variables. Natural Hazards. 57, 477-499.

Peduzzi, P., Chatenou, B., Dao, H., De Bono, A., Herold, C., Kossin, J., Mouton, F., and Nordbeck, O. (2012) Global trends in tropical cyclone risk. Nature Climate Change, 2, 289-294.

Penning-Rowsell,E.C, Sultana,S. Thompson, P.M (2013) The 'last resort'? Population movement in response to climate-related hazards in Bangladesh, Environmental Science \& Policy 27s: s44 - s59.

Pervin, M (2013) Mainstreaming climate change resilience into development planning in Bangladesh, Climate Change Country Report, London: IIED

Pervin, M. and Moin, M.I. (2014) Synergies in the financial landscape, The Dhaka Tribune, April 2014.

Planning Commission (2012) The Millennium Development Goals: Bangladesh Progress Report 2011. Dhaka: Planning Commission.

Planning Commission (2011) 6th five year plan (2011-2015) Accelerating Growth and Reducing Poverty, Part1 Strategic Directions and Policy Framework. Dhaka: Planning Commission, Government of the People's Republic of Bangladesh

Planning Commission (2010) Outline Perspective Plan of Bangladesh 2010-2021 (Vision 2021). Dhaka: Planning Commission.

Planning Commission (2009) 'Steps Towards Change, National Strategy for Accelerated Poverty Reduction 2: (FY 2009-2011). Dhaka: Planning Commission.

Planning Commission (2005) Bangladesh: Unlocking the Potential, National Strategy for Accelerated Poverty Reduction, Dhaka: General Economics Division, Planning Commission Government of People's Republic of Bangladesh.

Rahman M.M. (2009) Temporary migration and changing family dynamics: implications for social development. Population, Space and Place., 15: 161-174.

Rahman, M.M., Giedraitis, V.R., Lieberman, L.S., Akhtar, T., Taminskienè, V., Shrimp Cultivation with Water Salinity in Bangladesh: The Implications of an Ecological Model, Universal Journal of Public Health 1(3): 131142

Raillon, Camille (2010), Bangladesh Climate Disasters, Humanitarian practice challenged by populations 'resilience', edited by Veronique de Geoffroy and published by Urgence Rehabilitation Development and Rupantar, Bangladesh

This article is protected by copyright. All rights reserved. 
Rajya Sabha (2012) Answer by the Indian Minister of External Affairs S M Krishna to question no 130 in Rajya Sabha, the upper house of the Indian Parliament on March 22, 2012 http://www.idsa.in/resources/parliament/RefusalofillegalmigrationbyBangladesh accessed on March 23, 2017

Reckien, D., Wildenberg, M., Bachhofer, M. (2013) Subjective realities of climate change: how mental maps of impacts deliver socially sensible adaptation options, Sustainabilty Science, 8 (2) 159-172.

Rogaly, B (2009) 'Spaces of Work and Everyday Life: Labour Geographies and the Agency of Unorganised Temporary Migrant Workers', Geography Compass, 3 (6), pp1975-1987.

Roy, D. (2011). Vulnerability and Population Displacements due to Climate-Induced Disasters in Coastal Bangladesh. In: Leighton, M., Shen, X. and Warner, K. Climate Change and Migration: Rethinking Policies for Adaptation and Disaster Risk Reduction. Bonn, Germany: United Nations University Institute for Environment and Human Security (UNU-EHS). p22-31.

Saroar, M. M and Routray, J.K.. (2012). Impacts of climatic disasters in coastal Bangladesh: why does private adaptive capacity differ?. Regional Environmental Change. 12, p169-190.

Siddiqui, T (2011), Law Update Rationale of framing new emigration law The Daily Star, Dhaka, June 25

Siddiqui, T (2009) Climate change and Population Movement: the Bangladesh case, Paper presented at the Conference on Climate Insecurities, Human Security and Social Resilience, The RSIS Centre for Non-traditional Security Studies, Singapore, 27-28 August

Siddiqui, T and Farah, M. (2011) Facing the Challenges of Labour Migration from Bangladesh, Protifolon Policy Brief, 4, Dhaka: Institute of Informatics and Development

Siddiqui, T., Islam, M.T., Akhter, Z (2015) National Strategy on the Management of Disaster and Climate Induced Displacement. Dhaka: Comprehensive Disaster Management Programme II, Ministry of Disaster Management and Relief.

Smith, C., Wood, S. and Kniveton, D. (2010) Agent Based Modelling of Migration Decision-Making. In: Proceedings of the European Workshop on Multi-Agent Systems (EUMAS-2010).

Spaan, N. and Hillmann, F. (2005) Shifts in the European discourses on migration and development. Asian and Pacific Migration Journal, 14: 35-69

Stal, M.; Warner, K. (2009): The Way Forward. Researching the Environment and Migration Nexus. Research Brief based on the Outcomes of the 2nd Expert Workshop on Climate Change, Environment, and Migration. 23 - 24 July 2009, Munich, Germany. UNU-EHS. ISSN: 1816-5788. October 2009

Stark, O. and Bloom, D.E.,(1985) The new economics of labor migration. The American Economic review 75: 173-178.

Stern, N. (2007) The Economics of Climate Change: The Stern Review Cambridge: Cambridge University Press

Swain, A. (1996) Displacing the Conflict: Environmental Destruction in Bangladesh and Ethnic Conflict in India, Journal of Peace Research 33(2), 189-204.

This article is protected by copyright. All rights reserved. 
Sward, J. and Codjoe, S. (2012). Human mobility and climate change adaptation policy:a review of migration in National Adaptation Programmes of Action (NAPAs). Brighton: Migrating out of Poverty.

Tacoli, C (2011) Not only climate change: mobility, vulnerability and socio-economic transformations in environmentally fragile areas in Bolivia, Senegal and Tanzania. London: International Institute for Environmental and Development (IIED)

(2009). Crisis or adaptation? Migration and climate change in a context of high mobility. Environment and Urbanization. 21, p513-525.

(2013a) Population Facts No. 2013/3, Department of Economic and Social Affairs, Population Division September, New York: UN

United Nations (2013b) World Population 2012, Population Division, Department of Economic and Social Affairs, New York: UN [online]

http://esa.un.org/wpp/Documentation/pdf/WPP2012 Volume-I Comprehensive-Tables.pdf accessed on 16 June 2015

cial Affairs New York: UN

(2014) World Urbanization Prospects, The 2014 Revision, Highlights, Economic and So-

UNDP (2010) Mobility and Migration, A Guidance Note for Human Development Report Teams, Human Development Report Office, New York: UNDP

UNDP (2009) Human Development Report 2009, Overcoming barriers: Human mobility and development, New York: UNDP

UNFCCC (2011) Conference of the Parties, Report of the Conference of the Parties on its sixteenth session, held in Cancun from 29 November to 10 December 2010, Addendum, Part Two: Action taken by the Conference of the Parties at its sixteenth session

(2014) Bangladesh experiences with the NAPA process. [online] Available at: http://unfccc.int/adaptation/knowledge resources/ldc portal/bpll/items/6497.php [Accessed on 13 August 2014.]

Warner, K., Ehrhart, C., Sherbinin, A., Adamo, S. and Chai-Onn, T. (2009). In Search of Shelter: Mapping the Effects of Climate Change on Human Migration and Displacement. Geneva: CARE International.

WARPO (2006) Coastal Development Strategy Dhaka: Water Resources and Planning Organisation, Government of the People's Republic of Bangladesh.

World Bank (2005) Project performance assessment report, Bangladesh coastal embankment rehabilitation project (credit 2783-BD), Report No.: 31565, Sector, Thematic, and Global Evaluation Group, Operations and Evaluation Division, Washington DC: World Bank

(2015) Data, by country, Bangladesh [online] Available at http://data.worldbank.org/coun-

try/bangladesh. [Accessed on 16 June 2015.]

This article is protected by copyright. All rights reserved. 
World Bank (2016) Bangladesh, Country at a Glance http://www.worldbank.org/en/country/bangladesh accessed on March 31, 2016

Yanow, D. (1992) Silences in public policy discourse: organizational and policy mythes, Journal of Public Administration Research and Theory, Journal of Public Administration Research and Theory 2(4) 399-423

YPSA (2013) Bangladesh Housing Land and Property Rights Initiative, Report Prepared for Displacement Solutions Chittagong: Young Power in Social Action

This article is protected by copyright. All rights reserved. 